\title{
A RELEITURA DO DIREITO DO TRABALHO À LUZ DO PRAGMATISMO JURÍDICO
}

\section{HORÁCIO MONTESCHIO}

Pos doutorando na Universidade de Coimbra - Portugal e pelo UNICURITIBA, Paraná - Brasil. Doutor em Direito pela Faculdade Autônoma de São Paulo- FADISP. Mestre em Direitos da Personalidade - UNICESUMAR. Professor de Direito Administrativo Administrativo e Processo Administrativo do UNICURITIBA. Pós graduado em Direito Imobiliário e Direito processual civil pela Escola Paulista de Direito. Especialista em Processo Civil e Direito Público, pelo Instituto Brasileiro de Estudos Jurídicos, Direito Tributário, pela UFSC; em Direito Administrativo, pelo Instituto Romeu Felipe Bacellar; Direito Aplicado pela Escola da Magistratura do Estado do Paraná. Advogado, ex-Secretário de Estado da Indústria e Comercio e Assuntos do Mercosul do Estado do Paraná, ex-Secretário Municipal para Assuntos Metropolitanos de Curitiba; Integrante do Instituto dos Advogado do Paraná (IAP). Membro fundador e integrante do Instituto Paranaense de Advogados Eleitoralistas. Integrante das comissões de Direito Eleitoral e de Assuntos Legislativos da OAB/PR. ex-conselheiro do SEBRAE. ex-Presidente do Conselho da Junta Comercial do Estado do Paraná. Membro do Conselho Editorial do Instituto Paranaense de Direito Eleitoral.

\section{CLAYTON REIS}

Doutor em Direito pela Universidade Federal do Paraná (1999). Mestre em Direito pela Universidade Federal do Paraná (1996). Bacharel em Direito pela Faculdade de Direito de Curitiba (1970). Magistrado em Segundo Grau, aposentado, do TJPR. Professor na Escola da Magistratura do Paraná e pertence ao Corpo Docente Permanente do Programa de Mestrado em Direito Empresarial e Cidadania do UNICURITIBA. Realizou estágio Pós-doutoral na Faculdade de Direito da 
Personalidade Acadêmica Homenageada:

Carlos Aurélio Mota de Souza (Universidade Ibirapuera - UNIB)

Universidade de Lisboa-Portugal (2013). Tem experiência em: Direito Civil: Responsabilidade Civil, Dano Moral. Direitos da Personalidade e Cidadania.

\section{GUSTAVO AFONSO MARTINS}

Mestre em Direito Empresarial e Cidadania pelo Centro Universitário Curitiba UNICURITIBA. Curso em Direito Internacional Público e Direitos Humanos organizado pelo lus Gentium Conimbrigae - Centro de Direitos Humanos. Universidade de Coimbra-Pt. Advogado desde 2012. Pós Graduação pela Ematra Escola da Magistratura do Trabalho - 9a Região (2014); Pós Graduação pela Faculdade Integrada do Brasil - Unibrasil (2012) em Direito Público; Possui graduação em Direito pela Faculdade Dom Bosco - Campus Marumby (2011). Email: gustavoamartins.cwb@gmail.com

\section{RESUMO}

A pesquisa visa avaliar uma releitura do direito do trabalho, sua construção legislativa, sua vinculação à Constituição da República Federativa do Brasil, perpassando por teorias da justiça, a principiologia e do pragmatismo, a fim de buscar estabelecer diretrizes para compreender a nova sistemática deste direito. Observar-se-á para tanto, a influência econômica que perpassa pela estruturação e/ou motivação legislativa. Fazer a releitura do direito do trabalho a partir do pragmatismo jurídico, corrente de pensamento que surge nos Estados Unidos no século XIX, com o objetivo de correlacionar com a corrente tradicional do normativismo para propor uma maior aproximação entre $\mathrm{o}$ direito e a realidade mediante a valorização do trabalho humano, bem como do contexto e das consequências da interpretação jurídica. isso porque se presume haver um descompasso entre a tutela normativa no que tange direitos sociais, sobretudo, do trabalho, e a nova práxis referente as relações de trabalho, portanto, a ideia de releitura do direito laboral, embora possa ser realizada pelo viés do pragmatismo, ou 


\section{Personalidade Acadêmica Homenageada:}

Carlos Aurélio Mota de Souza (Universidade Ibirapuera - UNIB)

até da economia, seja análise econômica do direito, não se cogita relê-lo sem a perspectiva constitucional, vez que se a pretensão é a atualização dos direitos sociais - trabalho - melhor seria efetivá-los no novo contexto social, econômico e jurídico. O Estado Democrático de Direito se fortalece na medida em que há constante efetivação dos direitos fundamentais. Entretanto, o que se verifica, é uma preponderância do econômico em detrimento a direitos o que, em certa proporção se origina da influência do pragmatismo, que objetiva, em última análise, a abordagem prática e funcionalista do sistema normativo, assim, vincula-se àquilo que é útil. Ou seja, acaba por relativizar determinados direitos desde que o resultado social ou econômico pretendido seja mais eficiente. Essa preocupação como resultado útil e eficiência é uma constante no documento intitulado - 101 Propostas para Modernização trabalhista - elaborado pela Confederação Nacional da Indústria (CNI), que em certa medida fundamentou e/ou motivou a elaboração da Lei 13.467/2017 - Reforma Trabalhista - também consta na Lei de Introdução às normas do Direito Brasileiro, que dispõe, art. 20. "Nas esferas administrativa, controladora e judicial, não se decidirá com base em valores jurídicos abstratos sem que sejam consideradas as consequências práticas da decisão." Os direitos sociais, mais especificamente o direito do trabalho que é objeto deste artigo, se qualifica como avanço social conferidos à sociedade brasileira pela Constituição da República Federativa de 1988, os quais foram conquistados e reconhecidos após manifestações populares a fim da redemocratização e efetivação de direitos e garantias conquistados democraticamente para além da elaboração da norma unilateral do legislador constituinte originário. Por oportuno, é verificável que o pragmatismo possui aspecto positivo e negativo, de por um lado se pode analisar os resultados de determinadas escolhas, inclusive legislativa, também há, por outro, o aspecto negativo, verifica-lo apenas pela perspectiva econômica, de resultado útil.

Diante do exposto, o pragmatismo jurídico é um instrumento que deve ser manejado na esfera do direito com a finalidade de alcançar o objetivo contido no art. 3o da CRFB/88, caso instrumentalizado de forma alheia ao ideal de justiça, fundamentos e/ou objetivos da república federativa do Brasil, estar-se-á a valer-se de um mecanismo útil para uma finalidade ilegítima no campo do direito. Para tanto, 
Personalidade Acadêmica Homenageada:

Carlos Aurélio Mota de Souza (Universidade Ibirapuera - UNIB)

metodologicamente, vale-se do meio dedutivo e bibliográfico, pela na análise de doutrinas contemporâneas e jurisprudência.

PALAVRAS-CHAVE: Direito; Economia; Pragmatísmo; Justiça; Eficiência.

\section{REFERÊNCIAS}

ALEXY, Robert. Teoria de los derechos fundamentales. Centro de Estudios Constitucionales. Madrid, 1993.

ARRUDA, Thais Nunes de. Como os juizes decidem os casos difíceis? A Guinada pragmática de Richard Posner e a crítica de Ronald Dworkin. Dissertação (mestrado). Universidade de São Paulo: São Paulo, 2011. Disponível em: < http://www.teses.usp.br/teses/disponiveis/2/2139/tde-01032012085607/publico/Como_os_Juizes_decidem_os_casos_dificeis_Thais_Nunes_de_Arr uda.pdf $>$. Acesso em: 18/07/2014

BARROSO, Luís Roberto. O direito constitucional e a efetividade de suas normas. 5.ed. Rio de Janeiro, Renovar, 2001.

BRASIL. Constituição da República Federativa do Brasil de 1988. Disponível em: <http://www.planalto.gov.br/ccivil_03/constituicao/constituicaocompilado.htm>.

Acesso em: 15 nov. 2017.

Disponíve

Lei $\mathrm{n}^{\circ}$ 13.467, de 13 de julho de 2017. (Lei da Reforma trabalhista) 2018/2017/lei/L13467.htm>. Acesso em 5 de dez. 2017.

CANOTILHO, J.J. Gomes. Direito Constitucional e a Teoria da Constituição. 7.ed. Almedina, 2003

DWORKIN, Ronald. A justiça de toga. São Paulo: Martins Fontes, 2010.

. Justiça para ouriços. Coimbra: Almedina, 2012

FARAGE, Bruno da Costa Felipe. O pragmatismo antiteórico de Richard A. Posner e as respostas da teoria moral para a decisão judicial. Dissertação de Mestrado no Programa de Pós-Graduação em Direito da UERJ, 2015.

KELSEN, Hans. Teoria geral do direito e do Estado, 2005. 
Personalidade Acadêmica Homenageada:

Carlos Aurélio Mota de Souza (Universidade Ibirapuera - UNIB)

POGREBINSCHI, Thamy. O que é o pragmatismo jurídico? Disponível em: < http://www.cis.puc-rio.br/cis/cedes/PDF/paginateoria/pragmatismo.pdf> Acesso em: 05/09/2018

POSNER, Richard A. Law, pragmatism and democracy. Cambridge: Harvard University Press, 2005.

. Overcoming law. Cambridge: Harvard University Press, 1995. 